\title{
International ethics and governance for climate change amid the rise of BASIC
} countries

Zhu, Xianli

Published in:

International Social Science Journal

Link to article, DOI:

10.1111/issj. 12043

Publication date:

2015

Document Version

Peer reviewed version

Link back to DTU Orbit

Citation (APA):

Zhu, X. (2015). International ethics and governance for climate change amid the rise of BASIC countries. International Social Science Journal, 64(211), 55-74. https://doi.org/10.1111/issj.12043

\section{General rights}

Copyright and moral rights for the publications made accessible in the public portal are retained by the authors and/or other copyright owners and it is a condition of accessing publications that users recognise and abide by the legal requirements associated with these rights.

- Users may download and print one copy of any publication from the public portal for the purpose of private study or research.

- You may not further distribute the material or use it for any profit-making activity or commercial gain

- You may freely distribute the URL identifying the publication in the public portal

If you believe that this document breaches copyright please contact us providing details, and we will remove access to the work immediately and investigate your claim. 


\title{
International Ethics and Governance for Climate Change amid the Rise of BASIC Countries
}

Xianli Zhu

xzhu@dtu.dk

Copenhagen Centre on Energy Efficiency

Department of Management Engineering

Technical University of Denmark (DTU)

UN City

Marmorvej 51,

2100 Copenhagen $\varnothing$, Denmark

\section{Biiography:}

Xianli holds a PhD in Economics from the Chinese Academy of Social Sciences. She has been the UNEP DTU Partnership since 2006 (known as the UNEP Ris $\varnothing$ Centre until July 2014). Her main work areas include energy and climate policies, international climate change negotiation, climate change mitigation and adaptation technologies and carbon market mechanism. Her research is mainly focused on the Asia Pacific countries and major emerging economies.

\begin{abstract}
:
Climate change is a major environmental problem facing the world. In the United Nations climate change negotiations, a much-debated issue is which countries should reduce their greenhouse gas (GHG) emissions and who should bear the costs. In the process, since 2009 much attention has been focusing on a few big developing countries, especially the BASIC group countries. The rapid economic growth of some big developing countries in the past two decades is changing the landscape of the world economy and of development. In the climate change negotiations, big developing countries are often described as major polluters and barriers to reaching a new international climate agreement. This paper examines the recent rise of the big developing countries from an international development perspective. The process brings multiple development benefits both inside these countries and beyond their borders. The existing climate change commitments by developed countries are insufficient. A more equitable climate change regime should reflect countries' responsibilities for climate change and payment capability. Countries' per capita GHG emissions and per capita income should be used as key criteria of their climate change mitigation and adaptation, as well as international cooperation obligations. Finally, a more powerful international institution should be established to reflect the size and significance of the climate issue and effectively coordinate the international cooperation on climate change.
\end{abstract}

Key words: BASIC countries, climate negotiation, international climate ethics, international climate governance

\section{Introduction}


The rise of some big developing countries is changing the global distribution of economic power between the developed countries and developing countries. This increases global demand for oil and raw materials, pushes up their prices and makes these countries important contributors to global greenhouse gas (GHG) emission increases. During the international climate negotiations for a new global climate agreement, whether to keep the original country classification and obligation differentiation, or request that major developing countries commit to binding mitigation targets, has been a much debated issue and a key reason behind the blockade of international climate negotiations.

Although there are different definitions for emerging economies and major emitters, the BASIC countries (Brazil, China, India, and South Africa) have been a major interest group representing the positions and interests of big developing countries in the international climate negotiations during the last few years. These big developing countries first consolidated their negotiation positions in the climate negotiations in Copenhagen in 2009 and were noted as major forces shaping the Copenhagen Accords. These four countries continued their collaboration and regularly hold highlevel meetings to coordinate their climate negotiation positions and strategies.

This article will first give a brief introduction to the BASIC countries and the rise of developing countries. Then it will examine the national divisions in climate change mitigation and adaptation obligations under the UNFCCC and the Kyoto Protocol. The next section will discuss the rise of major developing countries from the context of sustainable development and highlight contributions of rapid growth in developing countries in achieving a more equitable world and the realization of the Millennium Development Goals. The penultimate section will highlight the energy and material needs for developing countries to catch-up with their developed counterparts, and the implications for a fair and more effective global climate governance system. Finally, the article will be summarized and some conclusions drawn.

\section{BASIC countries and the rise of developing countries}

The debut of the BASIC countries as a major force in international climate negotiations took place in 2009 during the negotiations of the Copenhagen Accord and since then, the BASIC countries have had 19 ministerial meetings on climate change by the end of 2014.

\subsection{The BASIC countries in climate negotiations}

The Kyoto Protocol only stipulates GHG emission reduction targets for developed countries for the first commitment period, 2008 to 2012. In the Kyoto Protocol, countries agreed that the negotiations for a subsequent commitment period should start at least seven years before the end of the first commitment period. After the Kyoto Protocol entered into force in 2005, the negotiations for a subsequent commitment period immediately started and were reflected in the very first Decision of the Conference of the Parties serving as the meeting of the Parties to the Kyoto Protocol (CMP) held in late 2005. The Stern Review was published in 2007, then the Intergovernmental Panel on Climate Change (IPCC) launched its Fourth Assessment Report in 2007 and Fifth Assessment Report in 2014, showing new evidence that climate change is caused by human activities and is taking place faster than expected, and that the loss and damage of delayed action would be bigger than previously 
estimated. Both reports concluded that it is much cheaper to take action to reduce climate change as opposed to taking no mitigation action, and calls for early and more effective mitigation and adaptation actions worldwide. In 2007, international negotiations for a new agreement also started among the Parties of the UNFCCC, and from 2007 to 2012 international climate negotiations took place under dual tracks: the UNFCCC and the Kyoto Protocol.

However, contentious issues remain around which countries should reduce GHG emissions, and who should pay for the mitigation costs, as well as how to cover the economic and human life losses due to climate change in poor countries. These poorer countries, with their low per capita GHG emissions and large number of poor people, are least responsible for climate change but are most vulnerable to climate change impacts. As a result, one issue is how to compensate these countries for the losses they suffer due to climate change and how to help them adapt to climate change, so as to avoid or reduce losses due to climate change impacts.

In December 2009, with wide expectations of reaching a new climate treaty, over 200 national leaders landed in Copenhagen, Denmark, during the last few days of the two-week international climate negotiation. Seeing the high risk of failing to reach an international agreement, Barak Obama, the US president, called for a closed door meeting with the leaders of Brazil, South Africa, India, and China (the BASIC countries) to broker a deal. The Copenhagen Accord was the result of closed-door negotiation and drafted by national leaders from 25 countries, including the United States, United Kingdom, Sweden, Spain, Saudi Arabia, Russia, Norway, Mexico, the Maldives, Lesotho, South Africa, Bangladesh, Algeria, Denmark, Germany, France, India, Ethiopia, Colombia, Korea, China, and Brazil (Dimitrov 2010). This is a deviation from the UN-led climate negotiation process of building on consensus of all participating countries. Econ Pöyry described this as "The US and BASIC redefines the UNFCCC game" in a research report written for the Norwegian government (Pöyry 2010, p.6).

Instead of setting binding targets only for developed countries, the Copenhagen Accord was based on the voluntary pledges of all countries, i.e. each country came up with its own targets for GHG emission reduction targets and measures. In return, developed countries together would provide additional climate change funding of 30 billion USD of quick kick-off funding for 2010-2012. It was also agreed that the size of international funding, including both private and public sources, should increase to 100 billion USD per year by 2020 .

\subsection{About the BASIC countries}

The term "BASIC countries" was first introduced in a 30-month project "Linking national and international climate policy: capacity building for challenges ahead for Brazil, China, India and South Africa" during 2005-2007 (BASIC project nd). This project was funded by the EU and the UK government and its overall objective was to link national and international climate policy by enhancing and strengthening institutional capacity on climate change in the BASIC countries.

Among the BASIC countries, the Chinese economy has been growing fast in the last twenty years, followed by India. The average annual economic growth rates of Brazil and South Africa are about average for developing countries, but less than half of the levels of India and China. Together, the four BASIC countries represent roughly 40 per cent of the world's population in 2010, more than 
twice the total of OECD countries (World Bank 2012). Each of the four BASIC countries is indisputably a regional power. In 2010, South Africa's economy contributed around 31 per cent of Sub-Saharan Africa's total GDP; Brazil accounted for 38 per cent of GDP in Latin America and the Caribbean, and India accounted for 80 per cent of GDP in South Asia; China had 19.4 per cent of the world population and contributed 35 per cent of the total GDP in the East Asia and Pacific region (World Bank 2012). Moreover, China is one of the five permanent members of the United Nations Security Council. Among the five UN Security Council members, it is the only member from the developing world. Moreover, China is a manufacturing centre of the world and has extensive trade and investment relations with most countries in the world.

It is not only these countries' economic rise that has drawn the attention of industrialised countries. All four BASIC countries have substantial and fast-growing GHG emissions, and in absolute terms (total tonnes per year), China is now the world's largest GHG emitter. In 2005, the four BASIC countries collectively accounted for nearly 60 per cent of the total annual GHG emissions from developing (non-Annex I) countries and almost 29 per cent of total global emissions - of which China alone produced almost 17 per cent.

Table 1. Average annual GDP growth Rate of the BASIC Countries

\begin{tabular}{|l|c|c|}
\hline \multirow{2}{*}{ Country } & \multicolumn{2}{|c|}{ Average growth rate (\%) } \\
\cline { 2 - 3 } & $1990-2000$ & $2000-10$ \\
\hline Brazil & 2.7 & 3.7 \\
\hline South Africa & 2.1 & 3.9 \\
\hline India & 5.9 & 8.0 \\
\hline China & 10.6 & 10.8 \\
\hline
\end{tabular}

Source: World Bank 2012

As indicated in Table 1, among the four BASIC countries, China and India have much faster economic growth than South Africa and Brazil. Their GHG emissions show a similar trend.

\subsection{The GHG emission profiles of the BASIC countries}

\section{GHG emission data availability}

The Kyoto Protocol covers six kinds of GHGs. Under the UNFCCC, Annex I countries are required to submit a national inventory about GHG emissions each year. However, the frequency of the submission of GHG emission data from developing countries is much lower. As of 2013, most developing countries have only submitted two National Communications, the initial communications contain countries' emission data in 1994, and the second national communications have been submitted more recently, and the GHG data in them are for the year 2000.

Among the six GHGs covered under the Kyoto Protocol, the data of carbon dioxide $\left(\mathrm{CO}_{2}\right)$ from energy consumption is more readily available, while the data about Land Use and Land Use Change (LULUCF) is generally less accurate. The International Energy Agency (IEA) systematically collects and releases data about countries' $\mathrm{CO}_{2}$ emissions from fuel combustion, but it does not provide data about $\mathrm{CO}_{2}$ 
emissions from other sources and the emissions of other GHGs. British Petroleum also updates and releases data about countries' energy production and consumption, as well as $\mathrm{CO}_{2}$ emissions, through its World Statistical Review on Energy.

Table 2 gives a quick overview of the GHG emissions of the BASIC countries and their trends.

Table 2. GHG emission profile of the BASIC Countries

\begin{tabular}{|c|c|c|c|c|c|c|c|c|}
\hline \multirow[t]{2}{*}{ Country } & \multicolumn{2}{|c|}{$\begin{array}{c}\text { Carbon dioxide }\left(\mathrm{CO}_{2}\right) \\
\text { emissions }\end{array}$} & \multicolumn{2}{|c|}{$\begin{array}{l}\text { Methane }\left(\mathrm{CH}_{4}\right) \\
\text { emissions }\end{array}$} & \multicolumn{2}{|c|}{$\begin{array}{c}\text { Nitrous oxide }\left(\mathrm{N}_{2} \mathrm{O}\right) \\
\text { emissions }\end{array}$} & \multicolumn{2}{|c|}{ Other GHG emissions } \\
\hline & $\begin{array}{c}2010 \\
\left(\mathrm{MtCO}_{2} \mathrm{e}\right) \\
*\end{array}$ & $\begin{array}{l}\text { \% change } \\
1990-2010\end{array}$ & $\begin{array}{c}2010 \\
\left(\mathrm{MtCO}_{2} \mathrm{e}\right)^{*}\end{array}$ & $\begin{array}{c}\text { \% change } \\
1990-2010\end{array}$ & $\begin{array}{c}2010 \\
\left(\mathrm{MtCO}_{2} \mathrm{e}\right) \\
*\end{array}$ & $\begin{array}{c}\% \\
\text { change } \\
1990- \\
2010\end{array}$ & $\begin{array}{c}2010 \\
\left(\mathrm{MtCO}_{2} \mathrm{e}\right) \\
*\end{array}$ & $\begin{array}{l}\% \text { change } \\
1990-2010\end{array}$ \\
\hline Brazil & 419.8 & $100.9 \%$ & 443.3 & $38.7 \%$ & 207.6 & $33.2 \%$ & 10.6 & $26.5 \%$ \\
\hline China & 8286.9 & $236.8 \%$ & 1624.3 & $61.5 \%$ & 550.3 & $72.8 \%$ & 249.4 & $1918.6 \%$ \\
\hline India & 2008.8 & $190.9 \%$ & 621.5 & $21 \%$ & 234.1 & $46.8 \%$ & 20.9 & $118.9 \%$ \\
\hline $\begin{array}{l}\text { South } \\
\text { Africa }\end{array}$ & 460.1 & $38 \%$ & 65.3 & $22.4 \%$ & 21.9 & $1.6 \%$ & 3.2 & $115.3 \%$ \\
\hline
\end{tabular}

Source: World Bank (World Development Indicators, Table 3.9) $2014\left(\mathrm{MtCO}_{2} \mathrm{e}=\right.$ million tonne $\mathrm{CO}_{2}$ equivalent).

\section{China's GHG emission profile}

With rapid economic growth since 1978, China's GHG emissions have also been growing much faster than the other three BASIC countries. Moreover, the majority of China's GHG emissions are $\mathrm{CO}_{2}$ emissions. However, since 1990, the emissions of chemical GHG gases, hydrofluorocarbons (HFCs), perfluorocarbons (PFCs), and sulfur hexafluoride $\left(\mathrm{SF}_{6}\right)$ (also known as F-Gases), have increased enormously, reflecting the rapid expansion of China's chemical industry. Compared to $\mathrm{CO}_{2}$, methane $\left(\mathrm{CH}_{4}\right)$ and nitrous oxide $\left(\mathrm{N}_{2} \mathrm{O}\right)$, F-Gases are the most potent $\mathrm{GHGs}$ because of their large heattrapping capacity and, in the cases of $\mathrm{SF}_{6}$ and the PFCs, their extremely long atmospheric lifetimes. Mitigating emissions of $\mathrm{F}$-Gases can be relatively inexpensive compared with mitigating $\mathrm{CO}_{2}$ emissions. China has implemented several Clean Development Mechanism Projects for the emission reduction of chemical GHGs.

Generally, China's high energy demand has been increasing rapidly and the main drivers behind its GHG emissions are economic growth, population increase, and its industry-dominated economic structure. The energy demand is mainly met by fossil fuel, especially coal and since 1978 coal has constantly contributed over two-thirds of China's primary energy consumption and about $80 \%$ of its electricity generation is based on coal (CNSB 2012).

China has also implemented some big afforestation and reforestation programmes and projects, with the result that its forest area expanded 525,000 square kilometers from 1990 to 2011, representing a 33\% increase (World Bank 2014). The carbon removal by the forestry sector offsets some of the GHG emissions from other sectors. 
India started its market deregulation in the 1990s, which ushered in a period of rapid economic growth, and which has been accompanied by fast growth in energy consumption and GHG emissions (see Table 2).

India's $\mathrm{GHG}$ emissions mainly consist of $\mathrm{CO}_{2}, \mathrm{CH}_{4}$ and $\mathrm{N}_{2} \mathrm{O}$. The main sources of $\mathrm{GHG}$ emissions in India are energy use, industry, and agriculture. Energy is a main issue as India relies on coal as the most important energy source - the country has relatively small oil and natural gas reserves, but sufficient coal. Agriculture, especially livestock, is the main source of $\mathrm{CH}_{4}$ emissions. Land use serves as a net carbon sink in India, in contrast to many developing countries where deforestation is a major source of emissions.

With their huge population, rapid economic growth, coal dominated energy structure, and high dependence on oil imports, China and India are a major concern to Western countries and to the projection of future world energy demand, oil markets, and GHG emission reduction. In 2007, the International Energy Agency focused its flagship publication, World Energy Outlook (IEA 2007) on China and India.

However, India's total annual GHG emissions are still much smaller than those of China and the USA. Due to its huge population, India's per capita $\mathrm{CO}_{2}$ emissions were only 1.5 tonnes in 2008 , much lower than the world average of 4.8 tonnes, and less than those of China (5.3 tonnes), Brazil (2.1 tonnes), and South Africa (8.9 tonnes) (World Bank 2012).

\section{South Africa's GHG emission profile}

South Africa had a population of only 50 million people in 2010 so its population is much smaller than other BASIC countries. Its GDP is not among the highest 20 in the world and its $\mathrm{CO}_{2}$ emissions ranked $18^{\text {th }}$ largest in 2010 (see Table 4). Unlike China and India, the growth speed of its GHG emissions since 1990 has been moderate. However, its per capita GHG emissions are by far the highest among African countries and also high by world standards. Owing to its abundant reserves of coal, its economy has attracted an array of large, energy-intensive industries. Around $40 \%$ of available electricity is consumed by energy intensive (and politically influential) users in the mining and industry sectors (Hallding et al. 2011).

\section{Brazil's GHG emission profile}

Compared with the other three BASIC Countries, Brazil has a very different GHG emission profile. As indicated in Table 2, Brazil's combined $\mathrm{CH}_{4}$ and $\mathrm{N}_{2} \mathrm{O}$ emissions were much greater than its $\mathrm{CO}_{2}$ emissions. As Table 3 shows, $44.6 \%$ of Brazil's $\mathrm{CO}_{2}$ emissions came from its transport sector in 2011, much higher than the proportions in the three other BASIC countries.

Table 3. Carbon dioxide emissions from fuel combustion by sector, 2011

\begin{tabular}{|l|c|c|c|c|c|}
\hline Country & $\begin{array}{c}\text { Electricity and } \\
\text { heat } \\
\text { production }\end{array}$ & $\begin{array}{c}\text { Manufacturing } \\
\text { industries and } \\
\text { construction }\end{array}$ & $\begin{array}{c}\text { Residential buildings } \\
\text { and commercial and } \\
\text { public services }\end{array}$ & Transport & $\begin{array}{c}\text { Other } \\
\text { sectors }\end{array}$ \\
\hline Brazil & $15.5 \%$ & $30.7 \%$ & $4.9 \%$ & $44.6 \%$ & $4.3 \%$ \\
\hline China & $53.6 \%$ & $31.3 \%$ & $5.7 \%$ & $7.8 \%$ & $1.6 \%$ \\
\hline
\end{tabular}




\begin{tabular}{|l|c|c|c|c|c|}
\hline India & $55.2 \%$ & $27.0 \%$ & $5.6 \%$ & $9.7 \%$ & $2.4 \%$ \\
\hline South Africa & $62.3 \%$ & $17.3 \%$ & $4.7 \%$ & $13.9 \%$ & $1.7 \%$ \\
\hline
\end{tabular}

Source: World Development Indicators 2014

The country's electricity generation is mainly from hydro, and in 2011 hydro contributed $81 \%$ of the total electricity generation in Brazil (World Bank 2014). Brazil is a leading country in the production, export, and use of biofuel, especially bioethanol, for transportation fuel. Therefore, energy accounts for a much smaller share of the country's total GHG emissions. Instead, deforestation is the most important source of GHG emissions from Brazil. From 1990 to 2011, Brazil's forest area shrank by 575,000 square kilometers, representing an average annual deforestation of about $0.5 \%$ and accounting for $40 \%$ of the deforestation worldwide over the same period (World Bank 2014). The country's GHG emission change has been relatively moderate by world standard.

\subsection{Other major economies and major GHG emitters among developing countries}

In international debate and studies of climate change negotiations, a lot of attention has been focused on the big countries and countries with big GHG emissions. When looking for strategies for climate change mitigation, one of the most debated topics is the rapid increase in some fast growing developing countries.

Table 4. The Biggest 20 Economies and $\mathrm{CO}_{2}$ Emitters Worldwide

\begin{tabular}{|l|l|c|l|l|c|}
\hline \multicolumn{3}{|c}{2010 GDP } & \multicolumn{3}{c|}{$\begin{array}{c}2010 \text { CO }_{2} \text { emissions from Fuel } \\
\text { Combustion }\end{array}$} \\
\hline Rank & Country & $\begin{array}{c}\text { GDP (bn 2005 } \\
\text { USD, PPP) }\end{array}$ & Rank & Country & $\begin{array}{c}\mathrm{CO}_{2} \\
\text { emissions } \\
\left(\mathrm{MtCO}_{2}\right)\end{array}$ \\
\hline 1 & USA & 13017.0 & 1 & China & 7258.5 \\
\hline 2 & China & 9417.1 & 2 & USA & 5368.6 \\
\hline 3 & Japan & 3895.3 & 3 & India & 1625.8 \\
\hline 4 & India & 3762.9 & 4 & Russia & 1581.4 \\
\hline 5 & Germany & 2732.5 & 5 & Japan & 1143.1 \\
\hline 6 & United Kingdom & 2020.9 & 6 & Germany & 761.6 \\
\hline 7 & Russia & 2010.4 & 7 & Korea & 563.1 \\
\hline 8 & Brazil & 1960.4 & 8 & Canada & 536.6 \\
\hline 9 & France & 1923.5 & 9 & Iran & 509 \\
\hline 10 & Italy & 1637.9 & 10 & United Kingdom & 483.5 \\
\hline 11 & Mexico & 1406.8 & 11 & Saudi Arabia & 446 \\
\hline 12 & Korea & 1320.9 & 12 & Mexico & 416.9 \\
\hline 13 & Spain & 1242.5 & 13 & Indonesia & 410.9 \\
\hline 14 & Canada & 1202.0 & 14 & Italy & 398.5 \\
\hline 15 & Indonesia & 930.7 & 15 & Brazil & 387.7 \\
\hline 16 & Turkey & 912.8 & 16 & Australia & 383.5 \\
\hline 17 & Myanmar & 839.1 & 17 & France & 357.8 \\
\hline 18 & Australia & 824.8 & 18 & South Africa & 346.8 \\
\hline 19 & Iran & 773.1 & 19 & Poland & 305.1 \\
\hline 20 & Chinese Taipei & 742.3 & 20 & Chinese Taipei & 270.2 \\
\hline$\%$ of world total & $76.8 \%$ & $\%$ of world total & $77.8 \%$ \\
\hline & & & &
\end{tabular}


In fact, the BASIC countries are not the only big economies or GHG emitters among the developing countries. As Table 4 shows, among the 20 biggest economies and $\mathrm{CO}_{2}$ emitters, there are both a number of developing countries as well as developed countries. China, India, and Brazil are big developing economies but apart from them, Korea, Indonesia, Turkey, Myanmar, Iran, and Chinese Taipei are also among the top 20 economies. Among the 20 big $\mathrm{CO}_{2}$ emitters, in addition to the BASIC countries, Korea, Iran, Saudi Arabia, Mexico, Indonesia, and Chinese Taipei are also on the list. Of course, big countries can also be defined in terms of population size or land area, but the most widely used parameters in climate negotiations are economy size and GHG emissions.

Table 5. Non-Annex I Countries with Fast Economic Growth and $\mathrm{CO}_{2}$ Emission Growth

\begin{tabular}{|l|c|l|c|}
\hline Country & $\begin{array}{c}\text { GDP Growth Rate } \\
(1990-2010)\end{array}$ & \multicolumn{1}{|c|}{ Country } & $\begin{array}{c}\mathrm{CO}_{2} \text { emission Growth } \\
\text { rate (1990-2010) }\end{array}$ \\
\hline Brazil & $82.6 \%$ & Brazil & $99.60 \%$ \\
\hline China & $580.10 \%$ & China & $223.50 \%$ \\
\hline India & $256.20 \%$ & India & $179.20 \%$ \\
\hline South Africa & $68.8 \%$ & South Africa & $36.70 \%$ \\
\hline Qatar & $594.00 \%$ & Vietnam & $658.50 \%$ \\
\hline Myanmar & $523.10 \%$ & Qatar & $361.70 \%$ \\
\hline Bosnia \& Herzegovina & $446.60 \%$ & Nepal & $313.10 \%$ \\
\hline Vietnam & $318.40 \%$ & Oman & $293.40 \%$ \\
\hline Mozambique & $264.80 \%$ & Bangladesh & $290.50 \%$ \\
\hline Singapore & $244.30 \%$ & Trinidad and Tobago & $276.30 \%$ \\
\hline Sudan & $223.10 \%$ & Sri Lanka & $256.40 \%$ \\
\hline Lebanon & $215.40 \%$ & Tanzania & $250.50 \%$ \\
\hline Malaysia & $211.90 \%$ & Ghana & $250.10 \%$ \\
\hline Angola & $211.30 \%$ & Lebanon & $241.20 \%$ \\
\hline Bahrain & $203.50 \%$ & Honduras & $238.30 \%$ \\
\hline Dominican Republic & $201.90 \%$ & Yemen & $236.70 \%$ \\
\hline Jordan & $198.80 \%$ & Panama & $228.70 \%$ \\
\hline Ethiopia & $193.90 \%$ & Guatemala & $221.20 \%$ \\
\hline Panama & $192.60 \%$ & Thailand & $208.70 \%$ \\
\hline World & $89.0 \%$ & World & $44.4 \%$ \\
\hline Non-Annex I & $189.4 \%$ & Non-Annex I & $144.7 \%$ \\
\hline Source:IEA & & &
\end{tabular}

Source: IEA 2012a

Moreover, even among the non-Annex I countries, quite a few have achieved remarkable economic growth from 1990 to 2010 . The number of countries with rapid $\mathrm{CO}_{2}$ emission growth is even bigger Table 5 above shows a list of developing countries that have seen higher than average GDP growth and $\mathrm{CO}_{2}$ emission growth among non-Annex I countries, and much higher than the world average growth rates.

As countries can be grouped using different indicators, different list are available about who are the emerging economies, the newly industrialised economies, the major economies, or the major emitters. For example, among the Group of Twenty (G20) countries, the developing country 
members include the BASIC countries, and Saudi Arabia, Turkey, Argentina, Mexico, Indonesia, South Korea (see G20 Research Group 2010). The Major Economies Forum on Energy and Climate (MEF) was launched on March 28, 2009. It is a US-led initiative to facilitate dialogue among major developed and developing economies, help generate the political leadership necessary to achieve a successful outcome at the annual UN climate negotiations, and advance the exploration of concrete initiatives and joint ventures that increase the supply of clean energy while cutting GHG emissions. Out of the 17 major economies participating in the MEF, the developing countries include Brazil, China, India, Indonesia, Korea, Mexico, and South Africa.

Financial institutions, consulting companies and researchers and experts also have their own list of emerging economies and newly industrialised countries. For example, the Financial Times divides the emerging economies in two groups in its Financial Times Stock Exchange Index (see Table 6 below).

Table 6. Emerging Markets in the FTSE (Financial Times Stock Exchange)

\begin{tabular}{|l|l|}
\hline $\begin{array}{l}\text { FTSE Advanced Emerging } \\
\text { Countries }\end{array}$ & $\begin{array}{l}\text { Brazil, Czech Republic, Hungary, Malaysia, Mexico, Poland, South } \\
\text { Africa, Taiwan, Turkey }\end{array}$ \\
\hline $\begin{array}{l}\text { FTSE Secondary Emerging } \\
\text { Countries }\end{array}$ & $\begin{array}{l}\text { Chile, China, Colombia, Egypt, India, Indonesia, Morocco, Pakistan, } \\
\text { Peru, Philippines, Russia, Thailand, UAE }\end{array}$ \\
\hline
\end{tabular}

Source: $\underline{\text { www.ftse.com/indices/FTSE Emerging Markets/ }}$

The rise of developing countries is a phenomenon with great influence on the world's development and environment and attracts attention from many sources. The UNDP focused its recent major publication, the Human Development Report, on the rise of developing countries (UNDP 2013).

\section{Country division and responsibility differentiation under the UNFCCC and the Kyoto Protocol}

\subsection{Country classification and responsibility differentiation under the UNFCCC}

The international cooperation and negotiation on climate change started with the United Nations Framework Convention for Climate Change (UNFCCC), which was negotiated during the 1992 Rio World Environment Summit and agreed in 1994. This is the first and also to date most important document on international climate change mitigation. The ultimate objective of the UNFCCC is the "stabilization of greenhouse gas concentrations in the atmosphere at a level that would prevent dangerous anthropogenic interference with the climate system". To achieve this objective, it established five principles: 1) common but differentiated responsibilities and respective capabilities;

2) full consideration of the specific needs and special circumstances of developing country Parties; 3 ) a precautious approach to climate change; 4) sustainable development; and 5) open economy.

The UNFCCC classified countries into two groups, Annex I countries and non-Annex I countries. The UNFCCC followed the country classification during the Cold War: basically the OECD countries, which were also referred to as the First World during the Cold War, and the Second World, the economies in transition. The UNFCCC, based on the principle of common but differentiated responsibilities and respective capabilities, stipulates different responsibilities and obligations for 
Annex II countries, Annex I countries, as well as non-Annex I countries (see Table 7). The 195 countries that have ratified the Convention are called Parties to the Convention.

Table 7. Different Responsibilities and Obligations under the UNFCCC for Different Country Groups

\begin{tabular}{|c|c|c|c|}
\hline & Annex I & Annex II countries & Non-Annex I Parties \\
\hline Countries & $\begin{array}{l}\text { OECD countries in } \\
1992 \\
\text { Plus economies in } \\
\text { transition (countries } \\
\text { from central and } \\
\text { eastern Europe, } \\
\text { former Soviet Union } \\
\text { members) }\end{array}$ & OECD countries in 1992 & $\begin{array}{l}\text { Countries other than } \\
\text { those in economies in } \\
\text { transition and OECD } \\
\text { countries, also widely } \\
\text { known as developing } \\
\text { countries }\end{array}$ \\
\hline Responsibilities & $\begin{array}{l}\text { - } \text { Regular reporting } \\
\text { - Annual GHG } \\
\text { inventory taking } \\
\text { and submission } \\
\text { - Commit to climate } \\
\text { change mitigation }\end{array}$ & $\begin{array}{l}\text { - Provide new and } \\
\text { additional finance to cover } \\
\text { agreed full cost by } \\
\text { developing countries for } \\
\text { information provision } \\
\text { under UNFCCC; } \\
\text { - Help particularly } \\
\text { vulnerable developing } \\
\text { countries in climate } \\
\text { change adaptation } \\
\text { - Promote, facilitate, and } \\
\text { finance transfer of climate } \\
\text { technologies to developing } \\
\text { countries }\end{array}$ & $\begin{array}{l}\text { Top priority is } \\
\text { poverty reduction } \\
\text { and contribute to } \\
\text { climate change } \\
\text { mitigation through } \\
\text { sustainable } \\
\text { development }\end{array}$ \\
\hline
\end{tabular}

Source: United Nations 1992

\subsection{Country responsibility differentiation under the Kyoto Protocol}

The Kyoto Protocol to the UNFCCC, which was reached in 1997, was a further elaboration of the UNFCCC. It further required countries listed in its Annex B (mainly developed countries and economies in transition) to take on binding targets for GHG emissions reduction which stipulated the targets for Annex I countries of the UNFCCC. In Annex B of the Kyoto Protocol, GHG emission targets were agreed for the Annex I countries during the first commitment period (2008-2012) (see Table 8). The targets have been set against the base year emissions, which in most cases is 1990 .

Table 8. GHG Emission Reduction Targets for Annex B Countries under the Kyoto Protocol

\begin{tabular}{|l|c|l|c|l|c|}
\hline EU-15 Members & $\begin{array}{l}\text { Kyoto } \\
\text { targets }\end{array}$ & $\begin{array}{l}\text { Economies in } \\
\text { Transition }\end{array}$ & $\begin{array}{l}\text { Kyoto } \\
\text { targets }\end{array}$ & $\begin{array}{l}\text { Other } \\
\text { countries }\end{array}$ & Kyoto targets \\
\hline European Community & $92 \%$ & Bulgaria & $92 \%$ & Australia & $108 \%$ \\
\hline Austria & $92 \%$ & Croatia & $95 \%$ & Canada & $94 \%$ \\
\hline Belgium & $92 \%$ & Czech Republic & $92 \%$ & Japan & $94 \%$ \\
\hline Denmark & $92 \%$ & Hungary & $94 \%$ & New Zealand & $100 \%$ \\
\hline Finland & $92 \%$ & Estonia & $92 \%$ & Norway & $101 \%$ \\
\hline
\end{tabular}




\begin{tabular}{|l|c|l|c|l|l|}
\hline France & $92 \%$ & Latvia & $92 \%$ & USA & $93 \%$ \\
\hline Germany & $92 \%$ & Lithuania & $92 \%$ & Iceland & $110 \%$ \\
\hline Greece & $92 \%$ & Poland & $94 \%$ & Monaco & $92 \%$ \\
\hline Ireland & $92 \%$ & Romania & $92 \%$ & Switzerland & $92 \%$ \\
\hline Italy & $92 \%$ & Russia & $100 \%$ & Liechtenstein & $92 \%$ \\
\hline Luxembourg & $92 \%$ & Slovakia & $92 \%$ & & \\
\hline Netherlands & $92 \%$ & Slovenia & $92 \%$ & & \\
\hline Portugal & $92 \%$ & Ukraine & $100 \%$ & & \\
\hline Spain & $92 \%$ & & & & \\
\hline Sweden & $92 \%$ & & & & \\
\hline UK & $92 \%$ & & & & \\
\hline
\end{tabular}

Source: Adapted from Annex B of the Kyoto Protocol (United Nations 1998)

In terms of GHG mitigation, the Kyoto Protocol does not request binding commitments from developing countries. Instead, the Clean Development Mechanism (CDM) was established, to encourage developing countries to implement GHG emission reduction projects, which can generate emission reduction credits that can be sold to developed countries. The purpose of such a flexible mechanism is to offer developed countries the option of buying credits for fulfilling their GHG emission reduction credits, instead of taking action at home, and for developing countries, it is expected that the CDM offers them extra international funding and low-emission reduction technologies, enabling these countries to contribute to global climate change mitigation, without compromising their pursuit for sustainable development.

The CDM proved to be a very effective mechanism - by January 2013, 6058 projects have been accepted as CDM projects by the UNFCCC secretariat and about 1.2 billion tonnes $\mathrm{CO}_{2}$-equivalent $\left(\mathrm{tCO}_{2} \mathrm{e}\right)$ of Certified Emission Reductions have been issued for these projects. Overall it is estimated that the CDM has successfully mobilized over 400 billion US dollars worth of investment, mainly from the private sector, in GHG emission reduction in developing countries (UNEP Risoe Centre, 2013). As most CDM projects can choose between a crediting period of 10 years fixed term or 7 years renewable twice, and many of these mitigation projects, be it energy generation from renewable sources, capturing methane for flaring or energy use, have a longer use life than their CDM crediting period, they are expected to generate several billons $\mathrm{tCO}_{2} \mathrm{e}$ of emission reductions. One remarkable phenomenon is that the majority of the CDM projects are concentrated in a few big developing countries, notably China, India, Brazil, South Korea, and Mexico, despite multiple international efforts to help more countries benefit from CDM. The reality is that the least developed countries and the small island countries have few projects, and those that do exist tend to be small in terms of GHG emission reduction.

\subsection{Implementation of the Kyoto Protocol and the international negotiations for extending the Kyoto Protocol}

\section{Implementation of the Kyoto Protocol}

Based on data submitted by countries to the UNFCCC website, Morel and Shishlov (2014) found that among the 36 Annex B countries that fully participated in the Kyoto Protocol, seven European 
countries and Japan failed to fulfill their emission reduction commitments for 2008-2012, the first commitment period of the Kyoto Protocol. Moreover, two other developed countries that eventually did not participate in the Kyoto Protocol, Canada and the United States, also emitted more than their mitigation targets. However, overall emissions from the participating countries were $24 \%$ lower than their emissions in the base year (which in most cases is 1990), surpassing the initial commitment of a $4 \%$ decrease. The main factors behind the overall success include large emission allowances from the Economies in Transition, which other developed countries could buy at cheap prices in order to meet their commitments, and the international financial crisis that reduced countries' GHG emissions.

Although it was the largest GHG emitter when the Kyoto Protocol was reached, the United States of America never ratified the Kyoto Protocol and therefore does not participate in the negotiations under the Kyoto Protocol. Given the size of the US economy and its GHG emissions, staying outside of the Kyoto Protocol significantly undermines its completeness and effectiveness.

Canada ratified the Kyoto Protocol in 2002 and its commitment under the Kyoto Protocol was to reduce its GHG emissions by $6 \%$ from the 1990 level during the first Kyoto Protocol Commitment Period (2008-2012). However, it did not take effective measures to achieve its mitigation targets and as a result, Canada's GHG emissions increased by $24.1 \%$ between the base year (1990) and 2010 (IEA 2012a), making it highly unlikely that the country would fulfill its commitment under the Kyoto Protocol. During the UN-led global climate negotiation in December 2011 in Durban, South Africa, the Canadian Minister of Environment formally announced Canada's withdrawal from the Kyoto Protocol.

Moreover, due to the significant increases in emissions in developing countries, the world's total anthropogenic GHG emissions in 2010 were 49 gigatonne carbon dioxide equivalent ( $\mathrm{GtCO}_{2} \mathrm{eq}$ ) in 2010, up from the $38 \mathrm{GtCO}_{2}$ eq in 1990; and the average annual growth rate was $2.2 \%$ between 2000 and 2010, much higher than the 1.3\% between 1970 and 2000 (IPCC 2014). The dramatic increases in energy consumption and GHG emissions of the BASIC Countries, especially China and India, made these countries the focus of attention in the studies, debate, and negotiations for effective reduction in global GHG emissions. In 1990, the base year of the Kyoto Protocol first commitment period targets, about $55 \%$ of the global GHG emissions came from OECD countries and Economies in Transition (Annex I countries). However, due to faster increases of GHG emissions from developing countries, by 2010, the 38 developed countries and economies in transition (including the US, which never ratified the Kyoto Protocol, and Canada, which ratified it but then withdrew from it) with mitigation targets under the Kyoto Protocol only contributed 39\% of the global GHG emissions during the year. This is also one of the reasons quoted by developed countries when refusing to undertake any new commitment under the Kyoto Protocol (Wheeler and Ummel 2007).

The IPCC's Fifth Assessment Report (2014) indicated that despite a growing number of climate change mitigation policies, annual GHG emissions grew on average by 1.0 gigatonne carbon dioxide equivalent $\left(\mathrm{GtCO}_{2}\right.$ eq) (2.2\%) per year from 2000 to 2010 compared to $0.4 \mathrm{GtCO}$ eq (1.3\%) per year 
from 1970 to 2000 . This makes it increasingly urgent for the global community to take effective actions to reduce GHG emissions to avoid dangerous climate change. The global emissions from fossil fuel combustion and industrial process, $\mathrm{CO}_{2}$ emissions from forestry and other land use, $\mathrm{CH}_{4}$ emissions from agriculture, energy and waste, $\mathrm{N}_{2} \mathrm{O}$ emissions from agriculture and other human activities, as well as the F-Gases, all grew significantly. As can be seen in Table 9 , in 2010, $76 \%$ of the global GHG emissions were $\mathrm{CO}_{2}$ emissions, while fossil fuel combustion and industrial process is the largest source of GHG emissions, contributing $65 \%$ of the total GHG emissions. Energy supply, industry, forestry, agriculture, transportation and residential and commercial buildings are the main sources of GHG emissions.

Table 9. Composition of global GHG emissions, 2010

\begin{tabular}{|l|c|}
\hline \multicolumn{1}{|c|}{ Gas } & $\begin{array}{c}\text { Share in total global annual GHG } \\
\text { emissions }\end{array}$ \\
\hline $\mathrm{CO}_{2}$ from fossil fuel combustion and industrial processes & $65 \%$ \\
\hline $\mathrm{CO}_{2}$ from Forestry and Other Land Use (FOLU) & $11 \%$ \\
\hline Methane $\left(\mathrm{CH}_{4}\right)$ & $16 \%$ \\
\hline Nitrous oxide $\left(\mathrm{N}_{2} \mathrm{O}\right)$ & $6.2 \%$ \\
\hline HFCs, CFCs, and $\mathrm{SF}_{6}$ (F-Gases) & $2.0 \%$ \\
\hline
\end{tabular}

Source: IPCC 2014

\section{Post-2012 climate negotiations under the Kyoto Protocol and the UNFCCC}

Climate change mitigation and adaptation is a long-term global environmental problem and the Kyoto Protocol's first commitment only covers five years. The negotiations for a subsequent commitment period were immediately covered in the negotiation schedule when the Parties of the Kyoto Protocol had its first annual meeting in 2005.

One of the key issues in climate negotiations is whether to continue the Kyoto Protocol or not. The developing countries highlight the principle of "common but differentiated responsibilities" under the UNFCCC, and called for continuation of the Kyoto Protocol; while a few developed countries, like the US, Japan, Canada, and Russia are against the idea of continuing the Kyoto Protocol. Finally, at the UN climate negotiation in December 2012 in Doha, Qatar, it was agreed to enter a second commitment period of 2013 to 2020 for the Kyoto Protocol (UNFCCC 2012). An eight-year extension to the Kyoto Protocol from 2013-2020 was signed by the EU, Norway, Switzerland, Australia, Monaco and Liechtenstein.

Japan, Russia, New Zealand and Canada refused to commit to further quantitative mitigation targets under the second commitment period of the Kyoto Protocol. The mitigation effects of the existing commitments will thus be limited, as a few big developed countries, including the US, are not part of it. 
The United Nations climate change negotiations have been following the rules of unanimous agreement, and the principle of one country, one vote. With 194 countries having ratified the UNFCCC and participating in the UN climate negotiations, plus the very divergent interests and development levels of these countries, it is extremely difficult to reach an agreement. Another thing the UNFCCC is lacks is an effective compliance mechanism. Countries voluntarily decide whether and when to ratify the UNFCCC and the Kyoto Protocol. The negotiations take place among the countries which have ratified the Kyoto Protocol and the UNFCCC.

The Kyoto Protocol did mention that if a country fails to meet its mitigation target in one commitment period, the country needs to make up the gap in the subsequent commitment period, plus a $25 \%$ penalty. However, Canada has already announced its refusal to undertake any commitment under a future Kyoto Protocol commitment period, which means the existing compliance mechanism will not affect it.

The negotiations under the UNFCCC, which covers all the Parties that decide to stay outside the Kyoto Protocol, started at the annual climate negotiations in 2007 in Bali, Indonesia, with the Bali Roadmap. Then in 2009, the Copenhagen Accord was reached, and most developed countries and over 40 developing countries signed up to voluntary pledges for domestic GHG mitigation targets and measures. In return, developed countries collectively promised to provide 30 billion US dollars of kick-off funding for the three-year period from 2010-2012 and the additional sources of funding from developed countries, including both public sources and private sources, to support mitigation and adaptation actions in developing countries will be increased to 100 billion dollars per year by 2020. But there is still no clear plan about how the funding will be raised.

During the post-2012 negotiations, the United States has made clear that it will not undertake any GHG mitigations unless the big developing countries do so. The EU also declared in 2007 that it would commit to reduce its emissions to $20 \%$ below the 1990 level by 2020, and if other major parties do the same, the EU is ready to make a deeper cut of 30\% below the 1990 level by 2020. Their main arguments include: 1) over half of the global GHG emissions now come from developing countries and developing countries are also the main source of further GHG emissions increases. Without the active participation of big developing countries, it is impossible to achieve the $2^{\circ} \mathrm{C}$ global climate targets no matter how much developed countries do; 2 ) it is cheaper to achieve emission reduction in developing countries, due to the use of less efficient technologies, and large amount of new investment; 3 ) international competition: if only developed countries are required to reduce their emissions, the incremental costs of emission reduction will make some production capacity move to developing countries and developed countries with stricter mitigation targets will find their enterprises and products less competitive on the international market.

\section{The rise of major developing countries from the context of sustainable development}

The UNFCCC is one of the conventions reached at the 1992 United Nations Conference on Environment and Development (UNCED), also known as the Earth Summit. The 1992 Earth Summit also agreed on the guiding principles of the global pursuit of sustainable development, including 
climate change mitigation and adaptation. In addition to the environment, the principles also emphasize the social and economic aspects of sustainable development:

- That human beings are at the centre of concerns for sustainable development. They are entitled to a healthy and productive life in harmony with nature;

- That eradicating poverty and reducing disparities in worldwide standards of living are "indispensable" for sustainable development.

Since the industrial revolution, humankind has made dramatic progress in technology and wealth creation. However, most of the wealth has been concentrated in the developed world - which only has around $20 \%$ of the world population. Meanwhile, dire poverty still exists in many parts of the developing world and billions of people in the developing world still suffer from hunger and malnutrition, and the lack of schools, clean water, access to electricity, and basic sanitary facilities. Elimination of extreme poverty and improving human dignity, equality and equity at the global level is still a big challenge facing the world. Helping poor countries develop their economies and protecting human rights, especially rights for survival and a decent life, is a common commitment shared by the global society.

In a United Nations resolution in October 1970, it was agreed that developed countries should donate at least $0.7 \%$ of their annual Gross National Income as official aid to developing countries. In 2012 , the net disbursement of official development aid from rich countries to developing countries was 127 billion dollars, 4 per cent lower than the peak in 2010. This is only 0.29 per cent of rich countries' Gross National Income, well below half of the UN target of 0.7 per cent (World Bank 2014).

At the Millennium Summit in September 2000 the largest gathering of world leaders in history adopted the UN Millennium Declaration, committing their nations to a new global partnership to reduce extreme poverty and setting out a series of time-bound targets, with a deadline of 2015. These have become known as the Millennium Development Goals (MDGs) and the eight MDGs are:

- Goal 1: Eradicate Extreme Hunger and Poverty

- Goal 2: Achieve Universal Primary Education

- Goal 3: Promote Gender Equality and Empower Women

- Goal 4: Reduce Child Mortality

- Goal 5: Improve Maternal Health

- Goal 6: Combat HIV/AIDS, Malaria and other diseases

- Goal 7: Ensure Environmental Sustainability

- Goal 8: Develop a Global Partnership for Development

BASIC countries are home to over $40 \%$ of the world population, or around half of the population in the developing world. Their rapid development has made significant contributions to the realization of the Millennium Development Goals. As mentioned above, among the BASIC countries, China and India have experienced much faster economic growth in the last two decades. This also results in significant decrease in extreme poverty in these two most populous countries on earth (See Table 10). In 1990, $60 \%$ of China's population lived below the international poverty line set by the World 
Bank, 1.25 US\$ per person per day; by 2008 , the proportion had shrunk to $13 \%$ and China achieved the MDG for poverty reduction ahead of schedule. India has also managed to lift hundreds of millions of people out of extreme poverty in the last two decades.

Table 10. Proportion of People living on less than 1.25\$ a day, 1990, 2005, and 2008 (percentage)

\begin{tabular}{|l|c|c|c|c|}
\hline & 1990 & 2005 & 2008 & MDG targets \\
\hline Sub-Sahara Africa & 56 & 52 & 47 & 28 \\
\hline India & 51 & 38 & 34 & 25.5 \\
\hline Southern Asia (excluding India) & 52 & 29 & 26 & 26 \\
\hline South Eastern Asia & 45 & 19 & 17 & 22.5 \\
\hline China only & 60 & 16 & 13 & 30 \\
\hline Latin America and Caribbean & 12 & 9 & 6 & 6 \\
\hline Western Asia & 5 & 5 & 3 & 2.5 \\
\hline Northern Africa & 5 & 3 & 2 & 2.5 \\
\hline Developing region (excluding China) & 41 & 31 & 28 & 20.5 \\
\hline Developing regions & 47 & 27 & 24 & 23.5 \\
\hline
\end{tabular}

Source: United Nations, The Millennium Development Goals Report 2012

The elimination of extreme poverty and hunger is the foundation of achieving several other MDGs, including MDG2: Achieving universal primary education, MDG3: promoting gender equality and empowering women, MDG 4: reducing child mortality rates, MDG 5: improving maternal health, and MDG 6: combating HIV/AIDS, malaria, and other diseases.

One indicator of the development benefits of the rise of BASIC countries and other developing countries is their electrification rate. Access to modern energy is an important measure for the eradication of extreme poverty. The correlation between access to cleaner energy and poverty reduction is corroborated by a number of recent World Bank studies: when the poor gain access to stable electricity supplies or cleaner fuels that can support job creation, trade, and value-adding activities within the family, they are able to accumulate the small levels of "surplus" or savings that facilitate access to education and health services, improved nutrition, or improved housing conditions that in turn enable them to gradually escape their poverty (UNDP 2006). The BASIC countries and some other developing countries have successfully expanded electricity supply to a large share of their population in the last two decades. Despite progress in the past year, nearly 1.3 billion people remain without access to electricity and 2.6 billion do not have access to clean-fuel cooking facilities. Ten countries - four in developing Asia and six in sub-Saharan Africa - account for two-thirds of those people without electricity and just three countries - India, China and Bangladesh - account for more than half of those without clean cooking facilities (IEA 2012b).

Increases in income also make more resources and capacity available for environmental protection. For example, since 2000, deforestation in Africa has decreased while in Asia, large scale afforestation efforts have led to increases in forest area in Asia (see Table 11).

Table 11 Net change in forest area between 1990 and 2000 and between 2000 and 2010

\begin{tabular}{|l|l|}
\hline $1990-2000$ & $2000-2010$
\end{tabular}




\begin{tabular}{|l|l|l|}
\hline & (m ha per year) & ( $\mathrm{m}$ ha per year) \\
\hline Africa & -4.1 & -3.4 \\
\hline Asia & -0.6 & 2.2 \\
\hline Europe & +0.9 & +0.7 \\
\hline North \& Central America & -0.3 & $<0.01$ \\
\hline Oceania & -0.04 & -0.7 \\
\hline South America & -4.2 & -4.0 \\
\hline
\end{tabular}

Source: United Nations, The Millennium Development Goals Report 2012

The rise of the BASIC countries also has impacts on the distribution of Official Development Aid (ODAs). With the increases in their per capita income level, these countries are receiving less and less international development aid, making a bigger share of the international ODA available for other developing countries. Moreover, they are increasing their development assistance to other developing countries. For example, China's contribution to the World Bank, the United Nations, the International Monetary Fund, and the Asian Development Bank has increased in the last decades and China has started to give ODAs and implement development assistance projects for African countries.

As indicated in Table 12, a major phenomenon in the world economy is the significant shifting in economic power distribution during the two decades from 1990 to 2010. The share of GDP by Annex I countries decreased from 70\% of the world GDP in 1990 to 54\% in 2010, meanwhile the economic share of non-Annex I countries increased from $30 \%$ to $46 \%$. As a whole, the economic gap between developing countries and developed countries has narrowed and developing countries' weight in the world economy has expanded.

Table 12 GDP Using Purchase Power Parities

\begin{tabular}{|c|c|c|c|c|c|c|c|}
\hline & \multicolumn{3}{|c|}{1990} & & \multicolumn{2}{|c|}{2010} & \multirow{2}{*}{$\begin{array}{c}\% \text { GDP } \\
\text { change } \\
90-10\end{array}$} \\
\hline & $\begin{array}{l}\text { bn } 2005 \\
\text { US\$ }\end{array}$ & $\begin{array}{l}\% \text { of world } \\
\text { total GDP }\end{array}$ & $\begin{array}{l}\% \text { of world } \\
\text { population }\end{array}$ & $\begin{array}{l}\text { bn } 2005 \\
\text { US\$ }\end{array}$ & $\begin{array}{c}\% \text { of } \\
\text { world } \\
\text { total GDP }\end{array}$ & $\begin{array}{l}\% \text { of world } \\
\text { population }\end{array}$ & \\
\hline World & 36208.9 & $100 \%$ & $100 \%$ & 68431.1 & $100 \%$ & $100 \%$ & $89.0 \%$ \\
\hline Annex I Parties & 25294.7 & $70 \%$ & $22.3 \%$ & 36842.2 & $54 \%$ & $18.9 \%$ & $45.7 \%$ \\
\hline Annex II Parties & 21380.9 & $59 \%$ & $15.2 \%$ & 31778.3 & $46 \%$ & $13.3 \%$ & $48.6 \%$ \\
\hline Annex I EIT & 3472.7 & $10 \%$ & $6.1 \%$ & 4832.3 & $7 \%$ & $4.4 \%$ & $19.3 \%$ \\
\hline Non-Annex I Parties & 10914.2 & $30 \%$ & $77.7 \%$ & 31589.0 & $46 \%$ & $81.1 \%$ & $189.4 \%$ \\
\hline Annex I Kyoto Parties & 16825.4 & $46 \%$ & $16.3 \%$ & 22784.3 & $33 \%$ & $13.1 \%$ & $35.4 \%$ \\
\hline Non-OECD Total & 12186.2 & $34 \%$ & $79.8 \%$ & 31317.8 & $46 \%$ & $81.9 \%$ & $157.0 \%$ \\
\hline OECD & 24022.7 & $66 \%$ & $20.2 \%$ & 37113.4 & $54 \%$ & $18.1 \%$ & $54.5 \%$ \\
\hline
\end{tabular}

Source: World Bank 2012

At the same time, from 1990 to 2010, the world population increased from 5.27 billion to 6.83 billion, representing a growth of $29.6 \%$. In 1990 , non-OECD countries were home to $79.8 \%$ of the world population. Due to their faster population growth, this share has expanded to $81.9 \%$. This indicates that on a per capita basis, the big development level divide still exists between developed countries and developing countries. 


\section{The catching-up of developing countries and the implications a global climate governance system}

The rapid development of developing countries is accompanied by urbanisation, economic structure change, the rapid expansion of housing and infrastructure, as well as mass consumption. The process is material and energy intensive.

Climate change mitigation is a typical global public good, because each country's emissions of GHGs contribute cumulatively to the increase of the overall concentration, and each country's abatements entail costs to itself, while the benefits are shared by all countries - there is no way to exclude any other country from enjoying the benefit of climate change mitigation. From an economics perspective, carbon dioxide emissions are a kind of environmental externality - a negative byproduct from the provision and consumption of energy services.

From the perspective of international ethics, GHG emissions have mainly come from fossil fuel combustion since the industrial revolution, and developed countries have much higher per capita historic emissions and current per capita emissions. Therefore, they should take the lead in reducing their per capita emissions to the global average per capita level, and compensating extremely vulnerable countries and people for the climate change-related losses they suffer and helping them adapt to climate change.

Developing countries, with their people having equal rights to a better standard of life, should be entitled to develop their economies. Meanwhile, they should, within their capability, improve the energy efficiency of their economy and reduce their energy and resource consumption, as well as GHG emissions. The existing international climate governance structure lacks an effective enforcement and compliance system. The high stakes of climate change makes it necessary to rectify this in order to promote climate change mitigation.

\subsection{The energy and material needs of the catching-up of developing countries}

The catching-up of developing countries to developed countries involves comprehensive transition: from a traditional agriculture-based rural economy to a modern industry and service-based urban economy. The process brings about improvement in living standards and lifestyle changes to large numbers of people. It is also a material and energy intensive process, due to increased demand for additional housing, public transport, education, jobs, health and other public facilities, and infrastructure networks within and between cities.

\section{Urbanisation}

One phenomenon accompanying the world's demographic change is urbanisation - an increasing share of the world population is living in cities. From 1990 to 2010, the world urbanisation rate increased by eight per cent (United Nations 2014). Although urbanisation happens in countries of all income levels, the fastest urbanisation took place in the middle-income countries (see Table 13). 
Among the BASIC countries, China and Brazil have experienced great change in the share of their populations living in urban areas when compared to middle income countries, on average.

Table 13. Urbanisation rate of different country groups and BASIC countries

\begin{tabular}{|l|c|c|}
\hline Country group & $\mathbf{1 9 9 0}$ & $\mathbf{2 0 1 0}$ \\
\hline Low income & 21 & 28 \\
\hline Middle income & 38 & 48 \\
\hline High income & 73 & 78 \\
\hline World & 43 & 51 \\
\hline Brazil & 75 & 87 \\
\hline China & 27 & 45 \\
\hline India & 26 & 30 \\
\hline South Africa & 52 & 62 \\
\hline
\end{tabular}

Source: World Bank 2012

According to World Urbanization Prospects - The 2014 Revision published by the United Nations (2014), 54 per cent of the world population resided in urban areas in 2011, and by 2050, it is expected that 62 per cent of the world population will be urban. Due to the high proportion of rural residents in their current population and high population growth, China and India are projected to have 700 million more urban residents by 2050, accounting for 28 per cent of the 2.5 billion global urban population growth. Nine other countries are projected to contribute 26 per cent of the urban increment: Nigeria and the Democratic Republic of the Congo in Africa; Bangladesh, Indonesia, Pakistan and the Philippines in Asia; Brazil and Mexico in Latin America, and the United States of America. Among them, those in Africa and Asia will experience high rates of urban population growth, usually surpassing 2 per cent or even 3 per cent per year.

\section{Economic structure exchange}

Another phenomenon that accompanies the catch-up phase of rapid development is change in economic structure, both in terms of GDP composition and employment in different sectors. In the least developed countries, the agriculture sector is typically the most important in GDP generation and employment. During the rapid development stage, with the improvement in labor productivity and the limited availability of arable land, a large proportion of the population move out of the agriculture sector and join the industrial and service sectors, which have higher productivity and offer high salaries. This shift means large investment in the industrial and service sector, with corresponding increases in energy and material demand.

\section{Living standard change and mass consumption}

The movement of people from rural to urban areas can result in greater production of goods and services, but it can also create congestion, pollution, and a greater demand for housing, clean water, sanitation facilities, recreation areas, public transport, health care and education. 
The ownership of cars and electrical appliances are more or less saturated in the developed world. The population growth is limited and housing demand increase is limited in turn. However, in the developing world, especially with household income growth, first the ownership of electrical appliances, like TV sets, refrigerators and washing machines increases, followed by the ownership of vehicles and housing. Table 14 shows the rapid increases in ownership of motorcycles, washing machines, refrigerators, colour TV sets, air conditioners, water heaters, computers, microwave ovens, as well as mobile phones and automobiles, among every 100 urban households in China. Both the production and use of these consumer goods demands enormous energy and leads to increases in the country's overall energy demand.

Table 14. Ownership of Durable Goods among Every 100 Urban Households in China

\begin{tabular}{|l|r|r|r|r|r|}
\hline \multirow{2}{*}{ Item } & \multicolumn{5}{c|}{ Number of Duarable Goods } \\
\cline { 2 - 6 } & \multicolumn{1}{|c|}{1990} & \multicolumn{1}{c|}{1995} & \multicolumn{1}{c|}{2000} & \multicolumn{1}{c|}{2005} & \multicolumn{1}{c|}{2008} \\
\hline Motorcycle & 1.94 & 6.29 & 18.80 & 25.00 & 21.39 \\
\hline Washing Machine & 78.41 & 88.97 & 90.50 & 95.51 & 94.65 \\
\hline Refrigerator & 42.33 & 66.22 & 80.10 & 90.72 & 93.63 \\
\hline Colour Television Set & 59.04 & 89.79 & 116.60 & 134.80 & 132.89 \\
\hline Air Conditioner & 0.34 & 8.09 & 30.80 & 80.67 & 100.28 \\
\hline Water Heater for Shower & & 30.05 & 49.10 & 72.65 & 80.65 \\
\hline Computer & & & 9.70 & 41.52 & 59.26 \\
\hline Microwave Oven & & & 17.60 & 47.61 & 54.57 \\
\hline Mobile Telephone & & & 19.50 & 137.00 & 172.02 \\
\hline Automobile & & & 0.50 & 3.37 & 8.83 \\
\hline
\end{tabular}

Source: China Statistical Yearbook 2010 (CNSB 2010)

In fact, the catch-up is also hard to achieve. In its 2010 Human Resource Report (UNDP 2010), the UNDP studied different countries' experiences with narrowing the gap with developed countries and concluded that among the 108 countries with incomes below $\$ 7,000$ per capita in 1970, only 4 moved up to the World Bank's high-income classification in 2010. Three of them are small island economies (Antigua and Barbuda, Equatorial Guinea and Malta), one with abundant oil. The fourth, South Korea, remains an important exception. Estonia and Slovakia, two of the eastern European countries that were re-established in 1990, have both achieved economic growth that moved them up onto the list of high-income countries.

\subsection{International justice in climate change mitigation and adaptation}

In the debate about creating a fair international climate governance system, different people argue for justice from different perspectives and using different parameters. As indicated in the IPCC Fourth Assessment Report and numerous new studies, climate change is already happening at higher frequency and severity, and the loss and damage due to climate change has been increasing. Unless, effective climate change mitigation measures are taken in time, the target of keeping global temperature rise within $2^{\circ} \mathrm{C}$ above the pre-industrial level is very likely to be missed. The results will 
be high global average temperature rises, melting of glaciers and permafrost, changes and greater variation in precipitation and climate patterns, inundation of large coastal and low-lying areas, human health and property losses, as well as extinction of large numbers of animal and plant species.

Although all countries are both emitters of GHGs and victims of climate change, their contribution to the problem and their vulnerability to climate change and the impacts they will suffer from climate change are determined by different factors. The least developed countries and small island countries, as well as poor social groups, who generally use less fossil energy and generate less GHG emissions on a per capita basis, are often the groups that are most vulnerable to climate change due to their greater livelihood reliance on natural resources and the climate system, as well as their lack of access to financial and technical resources to shield from the climate change events.

The Five Principles agreed by the 194 countries that have ratified the UNFCCC (discussed earlier) should therefore be more strictly followed in the international burden sharing of climate change mitigation.

\section{Countries' responsibilities for climate change}

As climate change is the result of GHG emissions, countries with high GHG emissions should take the lead in GHG emissions reduction. According to the Universal Declaration of Human Rights, all humans are equal before law and regulations, therefore each person should have the right to the same amount of the remaining GHG emission space. Countries with higher per capita emissions than their entitlement to the GHG emission quota for achieving the $2^{\circ} \mathrm{C}$ target should therefore be the first to take action to reduce their GHG emissions and give financial and technical support to extremely vulnerable countries with low emissions for using their emissions quota and reducing their future emissions. Due to the lack of latest country data about per capita GHG emissions, the per capita $\mathrm{CO}_{2}$ emissions from fossil fuel combustion, which is also the most important source of GHG emissions in most countries, can illustrate the great differences in per capita GHG emissions (see Table 15).

Table 15. Per capita $\mathrm{CO}_{2}$ emissions from fossil fuel combustion

\begin{tabular}{|l|l|l|l|}
\hline Country or country groups & tonne & Country or country groups & tonne \\
\hline World & 4.4 & Non-Annex I Parties & 2.8 \\
\hline Annex I Parties & 10.3 & Brazil & 2.0 \\
\hline OECD Europe & 7.0 & China & 5.4 \\
\hline US & 17.3 & India & 1.4 \\
\hline Australia & 17.0 & South Africa & 6.9 \\
\hline Canada & 15.7 & Middle East & 7.6 \\
\hline Japan & 9.0 & Africa & 0.9 \\
\hline Russia & 11.2 & Asia (excluding China) & 1.5 \\
\hline $\begin{array}{l}\text { Non-OECD Europe } \\
\text { and Eurasia }\end{array}$ & 7.7 & Non-OECD America & 2.3 \\
\hline
\end{tabular}

Source: IEA 2012a 
Even though the past GHG emissions from developed countries are not included in the calculation, most Annex I countries have much higher current per capita annual emissions than the developing countries. Therefore, these developed countries should take the lead in reducing their GHG emissions. One major reason behind the existing international climate regime is that developed countries with high per capita GHG emissions fail to accept their GHG mitigation responsibilities, instead they are trying to request that developing countries undertake ambitious emission reductions.

Under the principles of the UNFCCC, the developing countries should focus on sustainable development and take actions to reduce their GHG emissions and adapt to climate change under the framework of sustainable development. Their emissions should be allowed to increase to the extent that they could develop their economy and catch-up with developed countries.

\section{Damage compensation}

Stopping damaging behaviours immediately and compensating the victims for the damage caused is a common principle in the civil law of most countries, and is also one of the principles of global cooperation on environment and development issues in the Rio Declaration on Environment and Development: Principle 13, Compensation for Victims of Pollution and other Environmental Damage. The excessive GHG emissions from developed countries cause damage to poor and small island countries. Therefore the developed countries should give financial and technical support to help the highly vulnerable countries adapt to climate change and compensate them for the losses these countries suffer due to climate-change impacts.

\section{Payment capability}

When sharing domestic public costs, the most widely used principle for cost sharing is payment capability, in other words, the rich members of a society should contribute more for the common good. This approach is also followed in the UNFCCC principle, in requesting the Annex II countries (OECD members) to provide financing and technical support for the mitigation and adaptation actions in developing countries. This is also compatible with the "polluter-pay" principle. Furthermore, it is also in line with the fact that developed countries have accumulated large amounts of wealth and technology from their early industrialisation and the GHG emissions of their previous generations.

\subsection{Current commitments by major Annex I countries and non-Annex I countries for $\mathbf{2 0 2 0}$}

The current international climate regime is based on voluntary participation - each country decides whether it wants to participate or not, and the international agreement is applicable only to those countries which have ratified the international climate treaty.

Such an approach is more suitable for local environment issues, in which each country is the primary beneficiary of its environmental protection investment and efforts. Climate change mitigation is a pure public good - the costs are local while the benefits are international. The voluntary 
participation rule makes it easy for free-riding: countries avoid taking action and sharing their due burden but are still able to share the benefits of climate mitigation by other countries.

\subsection{The current commitment by developed countries is insufficient}

The existing emission reduction targets of the Annex I countries for 2020 lacks of ambition. Most of them are conditional on the actions by other developed countries or major developing countries, including the establishment of a new treaty; the economies in transition, which have an emissions allowance surplus that can be sold to other countries, also request continuous special treatment and flexible mechanisms (see Table 16).

Table 16. Quantified economy-wide emissions targets of major Annex I countries for 2020

\begin{tabular}{|c|c|}
\hline Country & Emissions reduction in 2020 \\
\hline $\begin{array}{l}\text { Australia } \\
\text { Base year: } \\
2000\end{array}$ & $\begin{array}{l}-5 \% \text { unconditional } \\
-15 \% \text { conditional upon: strict global treaty for } 450 \text { parts per million }(\mathrm{ppm})^{*} \mathrm{CO}_{2} \\
\text { equivalent }\left(\mathrm{CO}_{2} \text {-eq) }\right)^{*} \text { stabilisation targets, major developing economies commit to } \\
\text { substantially restrain emissions, advanced economies take on comparable } \\
\text { commitments } \\
-25 \% \text { conditional upon: an ambitious global deal capable of stabilising levels of } \\
\text { GHGs in the atmosphere at } \leq 450 \mathrm{ppm} \mathrm{CO}_{2} \text {-eq }\end{array}$ \\
\hline $\begin{array}{l}\text { Canada } \\
\text { Base year: } \\
2005\end{array}$ & $\begin{array}{l}-17 \% \text {, conditional to: the final economy-wide emissions target of the United States } \\
\text { in enacted legislation. }\end{array}$ \\
\hline $\begin{array}{l}\text { EU and its } \\
\text { Member } \\
\text { States } \\
\text { Base year: } \\
1990\end{array}$ & $\begin{array}{l}-20 \% \text { unconditional } \\
-30 \% \text { conditional upon: other developed countries committing themselves to } \\
\text { comparable emission reductions and that developing countries contribute } \\
\text { adequately according to their responsibilities and respective capabilities. }\end{array}$ \\
\hline $\begin{array}{l}\text { Japan } \\
\text { Base year: } \\
1990\end{array}$ & $\begin{array}{l}-25 \% \text { conditional upon: establishment of a fair and effective international } \\
\text { framework in which all major economies participate and on agreement by those } \\
\text { economies on ambitious targets. }\end{array}$ \\
\hline $\begin{array}{l}\text { Russian } \\
\text { Federation } \\
\text { Base year: } \\
1990\end{array}$ & $\begin{array}{l}\text {-15\% to }-25 \% \text { relative to its } 1990 \text { emissions and the range of its emission } \\
\text { reductions depend on two conditions: } \\
\text { - Appropriate accounting of the potential of Russia's forestry in the context } \\
\text { of its contribution to meeting the obligations of the anthropogenic } \\
\text { emissions reduction; } \\
\text { - All major emitters undertaking legally binding obligations to reduce } \\
\text { anthropogenic GHG emissions. }\end{array}$ \\
\hline $\begin{array}{l}\text { Ukraine } \\
\text { Base year: } \\
1990\end{array}$ & $\begin{array}{l}\text {-20\% conditional to: } \\
\text { - having the agreed position of the developed countries on quantified } \\
\text { emissions reduction targets of the Annex I countries; } \\
\text { - keeping the status of Ukraine as a country with an economy in transition } \\
\text { and relevant preferences arising from such status; } \\
\text { - keeping the existing flexible mechanisms of the Kyoto Protocol; } \\
\text { - keeping } 1990 \text { as the single base year for calculating Parties' commitments. }\end{array}$ \\
\hline USA & Target based on the assumption that other developed countries and more \\
\hline
\end{tabular}




\begin{tabular}{|l|l|}
\hline Base year: & $\begin{array}{l}\text { advanced developing countries would associate with the Copenhagen Accord and } \\
\text { submit mitigation targets accordingly. } \\
-17 \% \text { reduction by } 2020 \text { from the } 2005 \text { level, subject to domestic legislation. }\end{array}$ \\
& $\begin{array}{l}\text { Pathway set forth in pending legislation would entail a } 30 \% \text { emission } \\
\text { reduction by } 2025 \text { and a } 42 \% \text { emission reduction by } 2030 \text {, in line with the } \\
\text { goal to reduce emissions by } 83 \% \text { by } 2050 .\end{array}$ \\
\hline
\end{tabular}

Source: http://unfccc.int

Note: The Copenhagen Accord reached during COP15 in December 2009 called for developing countries to submit pledges for 'Nationally Appropriate Mitigation Actions' and developed countries to submit 'Quantified economy-wide emissions targets for 2020'. Most countries submitted their pledges or targets in 2010. However, in the negotiation process, a few countries have slightly changed their pledges or targets.

*ppm $\mathrm{CO}_{2}$-eq is the unit of GHG concentration in the atmosphere. For comparison, according to the IPCC's Fifth Assessment Report published in 2014, the GHG concentration is estimated to be 430 ppm $\mathrm{CO}_{2}$-eq in 2011 and the preindustrial level is $280 \mathrm{ppm} \mathrm{CO}$.

At COP 18 in Doha convened in December 2012, it was agreed that the international community should reach a new international climate treaty by 2015. It is still too early to say whether this could be achieved or not. The US Senate did not pass the Climate Change Bill, which means the US, the biggest economy in the world and the largest GHG emitter in the world, may not be able to fulfill its 2020 mitigation targets, which could conveniently give Canada an excuse for postponing mitigation action, and other Annex I countries an excuse to go for their lower mitigation targets for 2020. This kind of mutual conditionality is clear evidence of the ineffectiveness of the voluntary approach, which gives every country the incentive to take a wait-and-see attitude, opt for unambitious targets, and postpone mitigation action.

At the same time, the developed countries requested developing countries to take National Appropriate Mitigation Actions to address climate change. Table 17 shows the pledges by six major developing countries.

Table 17. Pledges of Major Developing Countries under the Copenhagen Accord

\begin{tabular}{|l|l|}
\hline Country & National Appropriate Mitigation Actions \\
\hline Brazil & $\bullet \quad$ Reduce $36.1 \%$ - 38.9\% of its projected emissions by 2020 \\
\hline China & $\begin{array}{l}\text { - Lower its carbon dioxide emissions per unit of GDP by } 40-45 \% \text { by } 2020 \text { compared to } \\
\text { the } 2005 \text { level } \\
\text { Increase the share of non-fossil fuels in primary energy consumption to around 15\% } \\
\text { by } 2020 \\
\text { Increase forest coverage by } 40 \text { million hectares and forest stock volume by } 1.3 \text { billion } \\
\text { cubic meters by } 2020 \text { from the } 2005 \text { levels. }\end{array}$ \\
\hline $\begin{array}{l}\text { India } \\
\text { Africa }\end{array}$ & $\begin{array}{l}\text { Endeavour to reduce the emissions intensity of its GDP by 20-25\% by } 2020 \text { in } \\
\text { comparison to the } 2005 \text { level. (Note: emissions from the agricultural sector will not form } \\
\text { part of the assessment of emissions intensity.) }\end{array}$ \\
\hline Indonesia & $\begin{array}{l}\text { Enable a } 34 \% \text { deviation below the "Business as Usual"* emissions growth trajectory by } \\
2020 \text { and a } 42 \% \text { deviation below the "Business As Usual" emissions growth trajectory by }\end{array}$ \\
\hline $\begin{array}{l}\text { Republic } \\
\text { of Korea }\end{array}$ & \begin{tabular}{l}
$-26 \%$ by 2020 from "Business as Usual" 2020 from "Business as Usual" \\
\hline
\end{tabular} \\
\hline
\end{tabular}


Source: http:/unfccc.int

*Business-as-usual (BAU) in 2020 refers to a country's estimated GHG emission level in 2020 without taking mitigation action against climate change. As it is not a fixed number and depends on multiple factors, different organisations may have different estimation about a country's BAU emission level for the specific year.

The UNFCCC also asked developed countries to provide financing and technical support to the adaptation actions in highly vulnerable countries but the existing funding is far from enough. The official funding support to mitigation actions is tiny compared to the huge amount of investment needed to realise the mitigation potential in developing countries. Little progress has been made in the transfer of climate change mitigation and adaptation technologies and know-how from developed countries to developing countries.

\subsection{A fair and more effective global climate governance system amid the rise of big developing countries}

The global population will continue to grow and the global economy will further expand for a long time. However, the resources and space of the planet Earth is limited. Countries need to improve the efficiency of their energy and resource use and pursue more sustainable development. Technology is the critical factor for improving the efficiency of energy and other resource use. Countries should cooperate in the research, development, and deployment of climate change mitigation and adaptation technologies, to more effectively protect the global climate system and reduce climate change loss and damage.

The 2007 IPCC report illustrated the different future emission levels in 2030 and 2010. For both years, one of the group of scenarios, the B1 storyline and scenario family, will be able to achieve the lowest GHG emissions. The B1 storyline is about a convergent world with the same global population, that peaks in mid-century and declines thereafter, but with rapid change in economic structures toward a service and information economy, with reductions in material intensity and the introduction of clean and resource efficient technologies. The emphasis is on global solutions to economic, social and environmental sustainability, including improved equity, but without additional climate initiatives (IPCC 2007).

For effective climate mitigation and adaptation, the existing policies and practices should be studied and the effective components of the Kyoto Protocol, like the Clean Development Mechanism, which is very effective in mobilising private investment in climate change mitigation, should be strengthened and made an important component for the post-2020 climate regime.

The form of international cooperation depends on the needs and significance of the specific issue at hand. The world has built some other more effective and powerful institutions, like the World Bank and International Monetary Fund, to pool resources and solve international issues for the stable operation of the international economy. The scale of the climate change issue and the human wellbeing at stake ensures the necessity of more powerful arrangements to oversee the proper design and effective implementation of a new international climate treaty.

\section{Conclusions}

Climate change is one of the top environmental challenges facing the world and demands urgent action from all countries. However, one issue constantly raised by developed countries is that their 
action depends on similar climate change mitigation efforts from the major developing countries or emerging economies. In climate negotiations, the major developing countries often mentioned are the BASIC countries. The history and background of the BASIC countries indicates that they are not unique - there are a number of other developing countries, which are also undergoing rapid economic growth and GHG emission increases.

The tackling of climate change needs to be done under the overall picture of globally sustainable and equitable development. The rise of major developing countries narrows the gap between the developed and developing worlds, and makes enormous contributions to poverty reduction and the realisation of Millennium Development Goals, disseminating the development benefits to hundreds of millions of people. However, the catch-up of developing countries to developed countries is also an energy and resource intensive process, and is combined with large scale and rapid urbanisation, industrialisation, as well as increases in mass consumption. In the climate negotiation and future climate regime designing process, the development rights and needs of developing countries should be fully recognised and protected.

A fair, equitable, and effective international climate regime serves the interests of all countries. When sharing the burdens of climate change mitigation and adaptation, the per capita emission levels and per capita income level should be used as main criteria. Also developed countries should do more to effectively reduce their own GHG emissions, help highly vulnerable countries adapt to climate change and compensate them for the climate change damage and loss they suffer, as well as provide funding and technical support to help developing countries pursue development with low GHG emissions.

The existing commitments by Annex I countries are insufficient. A more effective climate regime needs to be designed to encourage substantial action in climate change mitigation and adaptation, and international cooperation in climate technology research, development, and deployment. To guarantee more effective implementation and compliance, a more powerful institution needs to be established.

\section{References}

BASIC Project website. nd. Available from http://www.basic-project.net/ [26 March 2014].

CNSB, 2010, China Statistical Yearbook 2010, China National Statistical Bureau, Beijing.

CNSB, 2012. China Statistical Yearbook 2012, Beijing: China National Statistical Bureau.

Dimitrov R.S., 2010. Inside UN Climate Change Negotiations: The Copenhagen Conference. Review of Policy Research, 27 (6), 795-821.

G20 Research Group, 2010. G20 Members. Available from

http://www.g20.utoronto.ca/members.html [26 March 2014].

Hallding, K., Olsson, M., Atteridge, A., Vihma, A., Carson, M. and Román, M., 2011. Together Alone BASIC Countries and the Climate Change Conundrum, report to the Nordic Council of Ministers.

Stockholm: Stockholm Environment Institute.

IEA, 2007. World Energy Outlook 2007 - China and India Insights. International Energy Agency (IEA), Paris.

IEA, 2012a. $\mathrm{CO}_{2}$ Emissions From Fuel Combustion - Highlights (2012 Edition). International Energy Agency (IEA), Paris. 
IEA, 2012b. World Energy Outlook 2012. International Energy Agency, Paris.

IPCC, 2007. Climate Change 2007: Mitigation of Climate Change. Contribution of Working Group III to the Fourth Assessment Report of the Intergovernmental Panel on Climate Change, 2007. METZ, B., DAVIDSON, O.R., BOSCH, P.R., DAVE, R. AND MEYER, L.A. (eds). Cambridge University Press, Cambridge, United Kingdom and New York, NY, USA.

IPCC, 2014. Summary for Policymakers. In: Edenhofer, O., R. Pichs-Madruga, Y. Sokona, E. Farahani, S. Kadner, K. Seyboth, A. Adler, I. Baum, S. Brunner, P. Eickemeier, B. Kriemann, J. Savolainen, S. Schlomer, C. von Stechow, T. Zwickel and J.C. Minx (eds.), Climate Change 2014: Mitigation of Climate Change.Contribution of Working Group III to the Fifth Assessment Report of the Intergovernmental Panel on Climate Change. Cambridge University Press, Cambridge, UK and New York, NY, USA, 1-30.

Morel, R. and Shishlov, I., 2014. Climate Report No. 44 - Ex-post evaluation of the Kyoto protocol: Four key lessons for the 2015 Paris Agreement. CDC Climate Research, May.

Pöyry, E., 2010. BRIC, BASIC and Climate Change Politics: Status, Dynamics and Scenario for 2025. Pöyry Management Consulting (Norway) AS, 2010, Oslo. Commissioned by the Norwegian Ministry of the Environment.

Stern, N., 2007. The Economics of Climate Change: The Stern Review. Cambridge: Cambridge University Press.

UNDP, 2006. Energizing Poverty Reduction. A Review of Energy-Poverty Nexus in Poverty Reduction Strategy Paper. United Nations Development Programme (UNDP), New York, NY.

UNDP, 2010. Human Development Report 2010: The Real Wealth of Nations: Pathways to Human Development. United Nations Development Programme (UNDP), New York, NY.

UNDP, 2013. Human Development Report 2013: The Rise of the South: Human Progress in a Diverse World. United Nations Development Programme (UNDP), New York, NY.

UNEP Risoe Centre, 2013. UNEP Risoe CDM/JI Pipeline Analysis and Database, 1 February. Available from www.cdmpipeline.org [20 Feb 2013].

UNFCCC, 2012. Annual compilation and accounting report for Annex B Parties under the Kyoto Protocol for 2012. FCCC/KP/CMP/2012/9.

United Nations, 1998. Kyoto Protocol to the United Nations Framework Convention on Climate Change.

United Nations, 1992. United Nations Framework Convention on Climate Convention (UNFCCC).

United Nations, 2014. World Urbanization Prospects - The 2014 Revision: Highlights.

$S T / E S A / S E R . A / 352$. United Nations, Department of Economic and Social Affairs, Population Division.

Wheeler, D. and Ummel, K., 2007. Another Inconvenient Truth: A Carbon-Intensive South Faces Environmental Disaster, No Matter What the North Does. Center for Global Development. Working Paper 134, Washington DC, USA.

Winkler, H., 2011. Taking Action on Climate Change - Long Term Mitigation Scenarios for South Africa. Cape Town, UTC Press.

World Bank, 2012. 2012 World Development Indicators. World Bank, Washington D.C.

World Bank, 2014. 2014 World Development Indicators. World Bank, Washington D.C. 